\title{
Analisis Biaya Diferensial Dalam Pengambilan Keputusan Membeli Atau Memproduksi Sendiri Dan Analisis Biaya Peluang Pada RM. Pondok Hijau
}

\author{
Oleh: \\ Elvalina ${ }^{1}$ \\ David P.E. Saerang ${ }^{2}$ \\ Victorina Z. Tirayoh ${ }^{3}$ \\ Fakultas Ekonomi Dan Bisnis \\ Universitas Sam Ratulangi Manado \\ Email: ${ }^{1}$ elvalina94@gmail.com
}

\begin{abstract}
Economic growth in the era of globalization requires the company to gain maximum profit. Running business requires information. A company should be able to compete with other companies. One of the decisions that must be taken in planning at every alternative is to buy or produce itself a component of raw materials. Differential costs are related to the opportunity costs, which is the differential costs incurred costs as a result of certain decisions while the opportunity costs is the cost incurred when choosing a decision. The purpose of this study to analyze the differential costs in taking the decision to buy or produce itself and to analyze the opportunity cost to decisions taken on RM. Pondok Hijau. The analytical method used is descriptive quantitative. Result of differential costs analysis showed that the right decisions can be taken by the management company that manufactures its own because getting a higher differential gain, compared to buying from outside. And of the opportunity costs analysis produce itself rew materials are also more profitable, thus buying from outside becomes more expensive.
\end{abstract}

Keywords : Differential Cost, Opportunity Cost, Buy or Produce Itself

\section{PENDAHULUAN}

Pertumbuhan ekonomi bisnis di era globalisasi menuntut seluruh perusahaan untuk memperoleh keuntungan yang maksimal. Suatu perusahaan harus mampu bersaing dengan perusahaan - perusahaan lain. Sektor industri memegang peranan penting dalam perkembangan ekonomi karena perusahaan industri ini menyediakan kebutuhan masyarakat, serta dapat menyerap tenaga kerja yang banyak dan meningkatkan taraf hidup masyarakat.

Turunnya laju pertumbuhan sektor industri menyebabkan persaingan antara industri sejenis semakin ketat. Sehubungan dengan keadaan ini peran manajemen sangat penting dalam membantu perusahaan untuk mencapai tujuannya, yaitu untuk mempertahankan kelangsungan hidup perusahaan dengan mengoptimalkan sumber daya yang dimiliki perusahaan seperti mesin, material, modal, dan manusia secara efektif dan efisien juga untuk memaksimalkan laba perusahaan.

Berhasil tidaknya perusahaan dalam pencapaian tujuannya sangat bergantung pada manajemen perusahaan tersebut, apakah manajemen perusahaan sudah mampu mencapai tujuan perusahaan yang sebenarnya, baik itu untuk jangka pendek maupun untuk jangka panjang. Untuk mengukur berhasil atau tidaknya manajemen suatu perusahaan dilihat dari laba (keuntungan) yang diperoleh perusahaan.

Salah satu keputusan yang perlu di ambil dalam perencanaan pada setiap alternatif adalah membeli atau memproduksi sendiri suatu komponen bahan baku. Keputusan membuat atau memproduksi sendiri adalah keputusan manajemen menyangkut apakah sebuah komponen harus diproduksi sendiri ataukah dibeli dari pemasok lain. Karena berbagai macam 
alasan, sebuah perusahaan dapat memproduksi sebuah produk atau suatu jasa lebih murah dari pada perusahaan lain.

Biaya diferensial mempunyai hubungan dengan biaya peluang, dimana biaya diferensial adalah berbagai perbedaan biaya diantara sejumlah alternatif pilihan yang dapat digunakan perusahaan sedangkan biaya peluang adalah biaya yang dikeluarkan ketika memilih suatu keputusan jadi dalam perusahaan apabila biaya diferensialnya mengambil keputusan memproduksi sendiri maka biaya peluang yaitu membeli dari luar bahan baku.

RM. Pondok Hijau adalah perusahaan yang menjalankan usaha di bidang kuliner di mana dalam menjalankan aktivitas usahanya, perusahaan memerlukan bahan baku yang diperoleh dari luar perusahaan sehingga dapat dilihat dari kelancaran proses produksi dalam perusahaan, maka perusahaan harus berusaha menyediakan sesuai dengan kebutuhan.

Tujuan penelitian adalah

1. Untuk menganalisis biaya diferensial dalam pengambilan keputusan membeli atau memproduksi sendiri.

2. Untuk menganalisis biaya peluang terhadap keputusan yang di ambil.

\section{TINJAUAN PUSTAKA}

Hongren (2009: 4) Akuntansi adalah sistem informasi yang mengukur aktivitas bisnis, memproses informasi menjadi laporan keuangan, dan mengkomunikasikan hasilnya kepada para pembuat pengambil keputusan.

Kamaruddin (2009: 6) "Akuntansi adalah aktivitas-aktivitas yang berkaitan menyediakan informasi kepada pemegang saham, kreditur, dan pihak wewenang biasanya bersifat kuantitatif dan sering kali disajikan dalam satuan moneter, untuk pengambilan keputusan, perencanaan, pengendalian sumber daya dan operasi, mengevaluasi prestasi dan pelaporan keuangan para investor, kreditur, instansi yang berwenang serta masyarakat.

Berdasarkan definisi-definisi akuntansi terssebut, maka dapat disimpulkan bahwa akuntansi adalah proses pengolahan data keuangan untuk menghasilkan informasi keuangan yang digunakan untuk memungkinkan pengambilan keputusan memerlukan pertimbangan berdasarkan informasi dalam pengambilan keputusan.

Halim (2013: 3) Akuntansi manajemen adalah suatu kegiatan (proses) yang menghasilkan informasi keuangan bagi manajemen untuk pengambilan keputusan ekonomi dan melaksanakan fungsi manajemen.

Menurut Hansen (2012: 9) Akuntansi manajemen adalah mengidentifikasi, mengumpulkan, mengukur, mengklasifikasi, dan melaporkan informasi yang bermanfaat bagi pengguna internal dalam merencankan, pengendalian, dan pengambilan keputusan.

Definisi akuntansi manajemen yang lebih luas juga diberikan oleh Management Accounting of Accountants yaitu Akuntansi manajemen adalah proses identifikasi, pengukuran dan pengumpulan, analisis dan penyiapan komunikasi informasi financial yang digunakan oleh manajemen untuk perencanaan, evaluasi, pengendalian dalam suatu organisasi, serta untuk menjamin ketepatan penggunaan sumber-sumber dan pertanggungjawaban atas sumber-sumber tersebut.

Akuntansi dikelompokkan menjadi dua tipe, yaitu akuntansi keuangan dan akuntansi manajemen.Akuntani keuangan merupakan tipe akuntansi yang mengolah informasi keuangan yang terutama untuk memenuhi kebutuhan manajemen puncak dan pihak luar perusahaan.Sedangkan akuntansi manajemen merupakan tipe akuntansi yang mengolah informasi keuangan yang terutama untuk memenuhi keperluan manajemen dalam melaksanakan fungsi perencanaan dan pengendalian organisasi, Mulyadi (2007: 2).

Perbedaan - perbedaan pokok antara akuntansi keuangan dan akuntansi manajemen muncul karena kedua tipe akuntansi ini melayani pemakai informasi yang berlainan. Akuntansi keuangan biasanya ditujukan oleh pihak - pihak eksternal perusahaan seperti 
kreditor, pemilik, pajak, dan lain - lain. Sedangkan akuntansi manajemen ditujukan kepada pihak - pihak internal perusahaan (manajemen perusahaan) untuk pengambilan keputusan baik perencanaan, pengendalian, maupun penilaian kinerja.

Akuntansi keuangan adalah

1. Pengembangan dan pemakaian informasi akuntansi yang menggambarkan posisi keuangan yang sesungguhnya dan hasil operasi perusahaan.

2. Akuntansi keuangan berhubungan dengan penyiapan laporan keuangan untuk pengguna eksternal, seperti kreditur, investor dan pemasok.

3. Laporan keuangan meliputi : neraca,laporan laba rugi dan laporan perubahan posisi keuangan

4. Bagian dari akuntansi yang mengolah dan memberikan posisi keuangan dan hasil operasi bisnis

Akuntansi manajemen adalah

1. Bagian dari akuntansi yang mengolah dan memberikan informasi kepada manajer dalam suatu organisasi, membantu dalam perencanaan, pengambilan keputusan, dan pengawasan

2. Mengembangkan dan menginterpretasikan informasi akuntansi tertentu sesuai dengan kebutuhan manajemen perusahaan. Atau proses identifikasi, pengukuran, akumulasi, analisa, persiapan, interprestasi dan pemberitahuan informasi keuangan yang digunakan oleh manajemen untuk menyusun perencanaan, melakukan evaluasi dan kontrol dalam suatu organisasi.

3. Akuntansi yang berkaitan dengan penyediaan informasi bagi para manajer internal yang ditugasi mengarahkan, merencanakan, mengendalikan operasi dan pengambilan keputusan-keputusan manajemen.

Menurut Bambang Supomo (2012 : 103) pengertian Biaya Diferensial adalah sebagai berikut: "Biaya diferensial adalah biaya yang berbeda dalam suatu kondisi, dibandingkan dengan kondisi - kondisi yang lain". Menurut Darsono Prawironegoro (2009 : 259) pengertian biaya diferensial adalah sebagai berikut : "Biaya diferensial yaitu biaya yang berbeda - beda akibat adanya tingkat produksi yang berbeda yang mengakibatkan perbedaan biaya tetap". Sedangkan menurut Hansen dan Mowen (2005 : 339) yang diterjemahkan oleh Dewi Fitriasari mengatakan pengertian biaya diferensial adalah sebagai berikut : "Biaya diferensial merupakan biaya masa depan yang berbeda pada masing - masing alternatif".

Jadi, dapat disimpulkan bahwa biaya diferensial didefinisikan sebagai perbedaan biaya yang timbul akibat adanya keputusan tertentu. Misalnya manajemen melakukan penambahan volume produksi manajemen memilih alternatif proses produksi. Jika biaya diferensial itu disebabkan karena adanya penambahan volume produksi maka perbedaan itu dapat disebut dengan biaya incremental(Incremental Cost) atau biaya marginal(Marginal Cost).

Salah satu tugas pokok manajer adalah membuat keputusan berdasarkan informasi akuntansi yang relevan.Keputusan itu terdiri dari keputusan rutin dan keputusan khusus. Yang dimaksud keputusan rutin adalah keputusan operasi sehari - hari sesuai dengan fungsi fungsi manajemen (pemasaran, pruduksi, dan keuangan).

Menurut Darsono (2009 : 259) keputusan khusus yang diambil oleh manajer antara lain tentang

1. Menolak atau menerima order khusus

2. Menutup divisi atau mengembangkan

3. Membuat sendiri atau membeli produk

4. Menjual atau memproses lebih lanjut suatu produk

5. Menyewakan atau menjual fasilitas perusahaan

Berikut adalah penjelasan dari setiap keputusan - keputusan khusus di atas yang dijelaskan oleh Darsono : 


\section{Menolak atau Menerima Order Khusus}

Order khusus adalah penjualan yang harganya di bawah harga pasar karena perusahaan ingin menggunakan kapasitas yang menganggur. Misalnya kapasitas penuh dalah 1000 unit output, sekarang bekerja 800 unit output, sisa 200 unit output diproduksi kemudian dijual dengan harga di bawah harga pasar.

Order khusus diterima jika menambah laba operasi, dan sebaliknya ditolak jika mengurangi laba operasi. Untuk menentukan order khusus diterima atau ditolak harus menggunakan pendekatan Direct Costing dan Variable Costing, dimana seluruh biaya tetap dinyatakan sebagai beban. Dengan demikian yang dimaksud biaya produksi adalah hanya terdiri dari biaya variabel yaitu biaya bahan langsung, biaya tenaga kerja langsung, dan biaya overhead pabrik.

2. Mengembangkan atau Menutup Suatu Divisi atau Departemen

Suatu divisi pusat laba yang menderita kerugian pada umumnya akan ditutup. Namun untuk menutupnya harus diperhitungkan laba rugi secara keseluruhan.Jika secara keseluruhan organisasi mengakibatkan penurunan laba, maka divisi yang menderita kerugian itu diperkenankan terus beroperasi dengan jalan harus menguragi biaya agar dapat memperkecil kerugian.Kerugian suatu divisi pada umumnya disebabkan oleh perilaku biaya tetap.

3. Membuat Sendiri atau Membeli

Keputusan manajemen untuk membuat sendiri atau membeli dari pihak ketiga sesuatu produk, hakikatnya adalah masalah penggunaan peralatan untuk memproduksi produk yang paling besar memberikan sumbangan laba.Pertimbangan utama untuk memutuskan membuat sendiri atau membeli adalah biaya relevan, dimana kategori biaya yang diperhitungkan adalah biaya material langsung, upah langsung, overhead pabrik variabel.

4. Menjual atau Memproses Lebih Lanjut Suatu Produk

Perusahaan manufaktur adalah perusahaan yang mempunyai kegiatan utama mengolah bahan baku menjadi produk selesai. Permasalahan yang dijumpai terutama jika produk perusahaan diolah melalui beberapa departemen produksi.Hasil produksi dari suatu departemen produksi mungkin dapat langsung dijual ke pasar atau diolah lebih lanjut dalam departemen lanjutan. Dalam hal ini manajemen akan dihadapkan pada pilihan produk yang bersangkutan sebaiknya langsung dijual atau diproses lebih lanjut.

5. Menyewakan atau Menjual Fasilitas Perusahaan

Pengambilan keputusan manajemen dapat pula berkaitan dengan pemilihan alternatif menyewakan atau menjual fasilitas yang sudah tidak dipergunakan lagi dalam operasi perusahaan.Dalam pemilihan alternatif tersebut, manajemen harus pula mempertimbangkan pendapatan diferensial dan biaya diferensial.

Manajemen sering dihadapkan pada persoalan yang berkaitan erat dengan penggunaan bahan produksi. Di satu pihak perusahaan mempunyai fasilitas untuk memproduksi suku cadang tertentu, di pihak lain perusahaan dapat membeli suku cadang tersebut dari perusahaan lain. Jika fasilitas perusahaan untuk memproduksi suku cadang tersebut telah mencapai kapasitas penuh, maka untuk memenuhi kebutuhan proses produksi karena meningkatnya volume penjualan perusahaan, barangkali dapat dibenarkan jika perusahaan memutuskan untuk membeli kekurangan suku cadang yang diperlukan dari perusahaan lain. Akan tetapi dalam hal kapasitas perusahaan perusahaan untuk memproduksi suku cadang masih cukup tersedia, maka keputusan untuk membeli suku cadang dari luar harus mempertimbangkan biaya diferensial dan kemungkinan fasilitas perusahaan yang menganggur.

Pada dasarnya pengambilan keputusan yang menyangkut beberapa alternatif harus mempertimbangkan aspek kualitatif dan aspek kuantitatif dari pemilihan alternatif tersebut.Aspek kualitatif adalah segi yang tidak dapat diukur dari satuan uang dalam pengambilan keputusan.Misalnya dalam hal perusahaan memutuskan untuk membeli suku cadang dari luar sementara kapasitas perusahaan menganggur. Masalah yang perlu dipikirkan 
adalah pekerja yang menganggur, yang tidak akan memperoleh penghasilan jika upahnya dihitung berdasarkan satuan produk yang dihasilkan. Demikian pula jika manajemen memutuskan untuk meniadakan departemen tertentu dalam perusahaan.Bagaimana menangani karyawan dari departemen yang ditiadakan tersebut, merupakan permasalahan yang harus dipertimbangkan oleh manajemen. Jika karyawan tersebut dapat dipekerjakan pada departemen yang baru dibuka, tentunya diperlukan pelatihan bagi karyawan yang akan dipekerjakan pada departemen baru tersebut.

Menurut Mulyadi (2001 : 127) tentang keputusan membeli atau membuat sendiri adalah sebagai berikut :

"Keputusan membeli atau membuat sendiri dapat dibagi menjadi dua macam yaitu:

a. Keputusan membeli atau membuat sendiri yang dihadapi oleh perusahaan yang sebelumnya memproduksi sendiri produknya, kemudian mempertimbangkan akan membeli produk tersebut dari pemasok luar.

b. Keputusan membeli atau membuat sendiri yang dihadapi oleh perusahaan yang sebelumnya membeli produk tertentu dari pemasok luar, kemudian mempertimbangkan akan memproduksi sendiri produk tersebut".

\section{METODE PENELITIAN}

\subsection{Data}

Penelitian ini termasuk jenis penilitian deskriptif kuantitatif. Penelitian deskriptif merupakan dasar bagi semua penelitian. Penelitian deskriptif dapat dilakukan secara kuantitatif agar dapat dilakukan analisis statistik (Sulistyo-Basuki, 2006:110). Metode penelitian ini menganalisis masalah dengan cara mendeskripsikannya pada data yang sudah ada, berupa tabel perhitungan biaya produksi untuk mengetahui perbandingan biaya produksi ikan yang dapat memberikan gambaran maupun uraian jelas mengenai analisis biaya diferensial dan biaya peluang dalam pengambilan keputusan membeli atau memproduksi sendiri ikan pada RM. Pondok Hijau.

RM. Pondok Hijau adalah perusahan yang bergerak di bidang kuliner. RM.Pondok Hijau berlokasi di Desa Mapanget Minahasa Utara.Waktu penelitian kurang lebih selama 1 bulan yaitu bulan Febuari.

Prosedur penelitian yang dilakukan dalam skripsi ini adalah sebagai berikut :

1. Persiapan

Pada tahap ini mengajukan judul dan mencari objek penelitian yang sesuai dengan judul penelitian.

2. Mengumpulkan Data - Data

Pada tahap ini peneliti mengumpulkan data-data pendukung yang akan diperlukan dalam penyusunan skripsi, yaitu berupa gambaran umum perusahaan, struktur organisasi, biaya bahan baku, biaya tenaga kerja dan biaya overhead pabrik.

3. Menganalisis dan Mengelolah Data Penelitian

Setelah data terkumpul, tahap selanjutnya adalah tahap menganalisis dan mengolah data-data yang sudah di dapat.

4. Membuat Kesimpulan dari Hasil Penelitian

Setelah melewati semua tahap, penulis membuat kesimpulan dari hasil penelitian.

Jenis data terdiri atas

a. Data kualitatif, adalah data yang tidak dapat diukur dalam skala numerik. Data kualitatif merupakan data yang disajikan secara deskriptif atau bentuk uraian yang berupa gambaran umum perusahaan dan struktur organisasi (Kuncoro 2009: 145). Data kualitatif yang akan diambil seperti wawancara mengenai proses pengambilan keputusan membeli atau memproduksi sendiri. 
b. Data kuantitatif, data yang diukur dalam skala numerik. Data kuantitatif merupakan data yang disajikan dalam bentuk angka, berupa data-data biaya produksi dan data banyaknya jumlah produksi (Kuncoro 2009: 145). Data kuantitatif dalam penelitian ini yaitu data biaya produksi dalam usaha tersebut

Data penelitian terdiri atas

1. Data primer

Data primer merupakan data penelitian yang diperoleh dengan survey lapangan yang menggunakan semua metode pengumpulan data original (Kuncoro 2009: 148).

2. Data Sekunder

Data sekunder merupakan data yang dikumpulkan oleh lembaga pengumpulan data dan publikasikan kepada masyarakat pengguna data (Kuncoro 2009 : 148).

Dalam penelitian ini penulis menggunakan data primer yang berupa melakukan wawancara langsung dengan pengelolah atau pemilik perusahaan dan mendapatkan informasi dari RM. Pondok Hijau dalam hal ini pihak yang berwenang mengambil keputusan.

Teknik pengumpulan data

1. Penelitian Lapangan (Field Research)

Untuk memperoleh hasil penelitian yang diharapkan, maka diperlukan data dan informasi yang akan mendukung penelitian ini, maka sarana untuk memperoleh data dan hasil tersebut adalah :

a. Wawancara, yaitu teknik pengumpulan data dengan jalan mengadakan wawancara langsung dengan pihak-pihak yang berwenang dan bertanggung jawab untuk memberikan data dan keterangan yang dibutuhkan.

b. Pengamatan langsung adalah teknik pengumpulan data dengan cara mengamati dan meninjau secara langsung RM. Pondok Hijau. Dimaksudkan untuk mendapatkan keyakinan bahwa data yang diperoleh sebelumnya adalah benar untuk memperoleh gambaran yang nyata mengenai kegiatan operasi dari perusahaan tersebut.

2. Dokumentasi

Biaya variabel dan biaya tetap dan dokumen-dokumen terkait yang relevan dengan topik yang diteliti.

\subsection{Metode Analisis Data}

Metode analisis data yang digunakan dalam penelitian ini adalah analisis deskriptif, yaitu untuk menggambarkan berbagai karakteristik data yang berasal dari suatu sampel (Sujarweni, 2014:46). Dalam hal ini penulis mendeskripsikan dan menggambarkan data yang telah terkumpul serta menerapkannya sedemikian rupa sehingga dapat ditarik kesimpulan untuk menjawab permasalahan yang ada.

Penelitian ini juga menggunakan analisa Kuantitatif, dan analisis kuantitatif yang digunakan yaitu informasi akuntansi diferensial karena menghitung biaya produksi perusahaan,dengan cara membandingkan biaya produksi pada saat memproduksi sendiri ikan tersebut dengan harga ikan yang ditawarkan oleh pemasok.

\section{HASIL ANALISIS DAN PEMBAHASAN \\ 4.1.Hasil Analisis}

RM. Pondok Hijau sebagai salah satu rumah makan kuliner yang cukup terkenal dan memiliki banyak peminat. Rumah makan ini terkenal dengan menu andalan mereka yaitu paket ikan mujair bakar dan goreng, setiap paket harganya bervariasi yaitu paket besar harganya Rp.35.000, paket sedang harganya Rp.30.000, dan setiap paket terdiri dari nasi,ikan,dan sayur kangkung. Seiring berjalannya waktu dengan persaingan dalam usaha kuliner yang semakin ketat, maka RM. Pondok Hijau ini dengan kreatifitasnya menciptakan 
menu andalan lainnya seperti udang, ayam dan masih banyak menu andalan lagi yang dijual di RM.Pondok Hijau ini.

Berdasarkan informasi yang diperoleh dari RM.Pondok Hijau bahwa setiap harinya rumah makan ini menjual $100 \mathrm{~kg}$ ikan atau 300 ikan dengan harga per porsinya Rp. 30.000. Harga per porsi Rp.30.000 ini merupakan harga yang menjadi patokan perhitungan karena kebanyakan yang dijual ikan berukuran sedang. Untuk lebih memudahkan perhitungan, maka sangat diperlukan penggolongan biaya yang dapat berguna bagi RM.Pondok Hijau dalam pengambilan keputusan membeli atau membuat sendiri. Sebelum dilakukan analisis biaya diferensial dalam pengambilan keputusan membeli atau membuat sendiri perusahaan terlebih dahulu akan menganalisis dengan menyajikan data mengenai biaya bahan baku, biaya tenaga kerja langsung, dan biaya overhead dalam produksi.

Pada tabel 4.1 biaya untuk memproduksi ikan berjumlah Rp. 638.600.000 dimana biaya-biaya produksi tersebut berupa biaya bahan baku langsung sebesar Rp.542.400.000, biaya tenaga kerja langsung sebesar Rp. 90.000.000, dan biaya overhead pabrik sebesar Rp. 6.200.000 dan dalam penelitian ini menggunakan metode penyusutan garis lurus.Berikut ini adalah data biaya produksi ikan periode 2014:

Tabel 4.1. Biaya Produksi Ikan Periode 2014 ( Ukuran Luas Telaga $20 \times 40 \mathrm{~meter}^{2}$ )

\begin{tabular}{|c|c|c|c|c|c|}
\hline $\begin{array}{c}\text { Biaya } \\
\text { Produksi }\end{array}$ & Keterangan & Jumlah Unit & $\begin{array}{c}\text { Harga per } \\
\text { Unit }\end{array}$ & & Total \\
\hline Bahan Baku & -Bibit & 108.000ekor & Rp. 300 & Rp. & 32.400 .000 \\
\hline Langsung & -Pelet & $1200 \mathrm{~kg}$ & Rp. 425.000 & $\mathrm{Rp}$. & 510.000 .000 \\
\hline Biaya Tenaga & & 60 orang & Rp. 1.500 .000 & $\mathrm{Rp}$. & 90.000 .000 \\
\hline Kerja langsung & & & & & \\
\hline \multirow{6}{*}{$\begin{array}{l}\text { Biaya Overhead } \\
\text { Pabrik }\end{array}$} & -Penyusutan & & & Rp. & 1.200 .000 \\
\hline & Peralatan & & & & \\
\hline & -Biaya & & & Rp. & 1.000 .000 \\
\hline & Listrik & & & & \\
\hline & -Penyusutan & & & Rp. & 4.000 .000 \\
\hline & Mesin & & & & \\
\hline TOTAL & & & & Rp. & 638.600.000 \\
\hline
\end{tabular}

Sumber :Hasil data olahan, 2015

1. Biaya Bahan Baku

Biaya bahan baku yang di keluarkan rumah makan untuk memproduksi ikan selama 1 tahun yaitu Rp. 542.400.000, dimana bahan baku tersebut berupa bibit sebesar Rp. 32.400.000 dan pelet sebesar Rp. 510.000.000. Berikut ini adalah biaya bahan baku untuk memproduksi ikan periode 2014 :

Tabel 4.2. Biaya Bahan Baku Untuk Memproduksi Ikan periode 2014

\begin{tabular}{lcc}
\hline & Bahan Baku & Biaya/Tahun \\
\hline Bibit & Rp 32.400 .000 \\
Pelet & Rp. 510.000 .000 \\
& TOTAL & Rp. $\mathbf{5 4 2 . 4 0 0 . 0 0 0}$
\end{tabular}

Sumber :Hasil data olahan, 2015

Adapun perhitungan yang telah dilakukan di atas memiliki rincian :

$>$ Bibit 
Dalam sehari RM.Pondok Hijau memproduksi $100 \mathrm{~kg}$ ikan untuk dijual, jadi perhitungannya :

Perhitungan Dalam satuan

- $1 \mathrm{~kg}$ ikan = 3 Ikan

- $100 \mathrm{~kg} \mathrm{x} 3=300 \mathrm{Ikan}$

- $300 \times 30=9.000$ Ikan (Sebulan)

- $9.000 \times 12=108.000$ Ikan (Setahun)

Perhitungan Dalam Kilogram $(\mathrm{kg})$

- $100 \mathrm{~kg} \mathrm{x} 30=3000 \mathrm{~kg}$ (Sebulan)

- $3000 \times 12=36.000 \mathrm{~kg}$ (Setahun)

Jadi, dalam setahun RM.Pondok Hijau memproduksi 108.000 ikan atau $36.000 \mathrm{~kg}$ dan harga bibit per unit yaitu Rp.300 berukuran 3-4 cm

$>$ Pelet

Untuk ikan sebanyak 108.000 dalam setahun para pekerja memberi makan sebanyak $1200 \mathrm{~kg}$ itu di dapat dari :

- 1 karung $=50 \mathrm{~kg}$

- 1 bulan $=100 \mathrm{~kg}(2 \mathrm{karung})$

- 1 tahun $=12 \times 100$

$$
=1.200 \mathrm{~kg}(24 \mathrm{karung})
$$

- $\quad$ Harga 1 karung = Rp. 425.000

Jadi, 1.200 x Rp. $425.000=$ Rp. 510.000 .000

2. Biaya Tenaga Kerja Langsung

RM. Pondok Hijau mempunyai 20 tenaga kerja yang terbagi atas : koki 3 orang , pelayan 8 orang, bagian pembelian 2 orang dan kasir 2 orang dengan gaji atau upah yang berbeda-beda.

Dalam memproduksi ikan RM.Pondok Hijau mempekerjakan 5 orang tenaga kerja yang bertugas untuk memproduksi ikan dengan gaji sebesar Rp. 1.500 .000 per bulan jadi pehitungannya :

- 5 orang x Rp. $1.500 .000=$ Rp. 7.500 .000

- Rp. $7.500 .000 \times 12=\mathrm{Rp} 90.000 .000$

Jadi,dalam setahun RM.Pondok Hijau membayar biaya tenaga kerja langsung sebesar Rp. 90.000.000.

3. Biaya Overhead Pabrik

Data biaya Overhead pabrik yang dikeluarkan oleh rumah makan yaitu :untuk penyusutan peralatan sebesar Rp.1.200.000, Biaya listrik sebesar Rp.1.000.000, dan Penyusutan mesin sebesar Rp. 4.000.000, sehingga total yang dikeluarkan oleh rumah makan untuk biaya overhead pabrik adalah Rp. 6.200.000. Berikut ini adalah data biaya overhead pabrik untuk memproduksi ikan :

Tabel 4.3. Biaya overhead pabrik untuk memproduksi ikan Periode 2014

\begin{tabular}{ll}
\hline \multicolumn{1}{c}{ Keterangan } & Jumlah \\
\hline Penyusutan peralatan & Rp. 1.200 .000 \\
Biaya Listrik & Rp. 1.000 .000 \\
Penyusutan mesin & Rp. 4.000 .000 \\
\multicolumn{1}{c}{ Total } & Rp. 6.200.000
\end{tabular}

Sumber :Hasil data olahan, 2015

Untuk menghitung Biaya Overhead dalam memproduksi ikan adalah sebagai berikut : 
- Penyusutan Peralatan

Jala, Waring (anco), ember-ember, baskom berbagai ukuran, timbangan, cangkul, pisau, piring secchi (untuk mengukur kadar kekeruhan) dll.

(Harga perolehan Rp. 6.000.000) (Masa manfaat 5 tahun)

Tidak ada nilai sisa

Penyusutan per tahun : Rp.6.000.000 x 20\% = Rp. 1.200 .000

Penyusutan per bulan $:$ Rp. $1.200 .000=$ Rp. 100.000

12

- Biaya Listrik

(Harga perolehan Rp. 5.000.000) (Masa manfaat 5 tahun)

Tidak ada nilai sisa

Biaya Listrik per tahun : Rp. $5.000 .000 \times 20 \%=$ Rp. 1000.000

Biaya Listrik per bulan : $: \frac{\text { Rp. } 1.000 .000}{=}=\mathrm{Rp} .83 .333 .33$

12

- Penyusutan Mesin

Pompa Air Sanyo (Rp. 4.000.000) dan Generator kapasitas 2500 watt (Rp.16.000.000)

(Harga perolehan Rp. 20.000.000) (Masa manfaat 5 tahun)

Tidak ada nilai sisa

Penyusutan per tahun : Rp. 20.000 .000 x $20 \%=$ Rp. 4.000 .000

Penyusutan per bulan $: \underline{\text { Rp. } 4.000 .000}=$ Rp.333.333.3

12

Keterangan : $20 \%$ dari $\underline{100 \%}=0,2=20 \%$

5 tahun

\section{Tinjauan Berdasarkan Biaya Differensial}

Alternatif selain membuat sendiri adalah membeli dari pemasok luar. Harga beli persatuan $\mathrm{kg}$ Ikan adalah sebesar $\mathrm{Rp}$ 25.000,- selisih antara membeli dari luar atau memproduksi sendiri ikan tersebut dapat dilihat dari tabel 4.4 dibawah ini :

Tabel 4.4. Perbandingan Biaya Diferensial Membeli Atau Memproduksi Sendiri Periode 2014

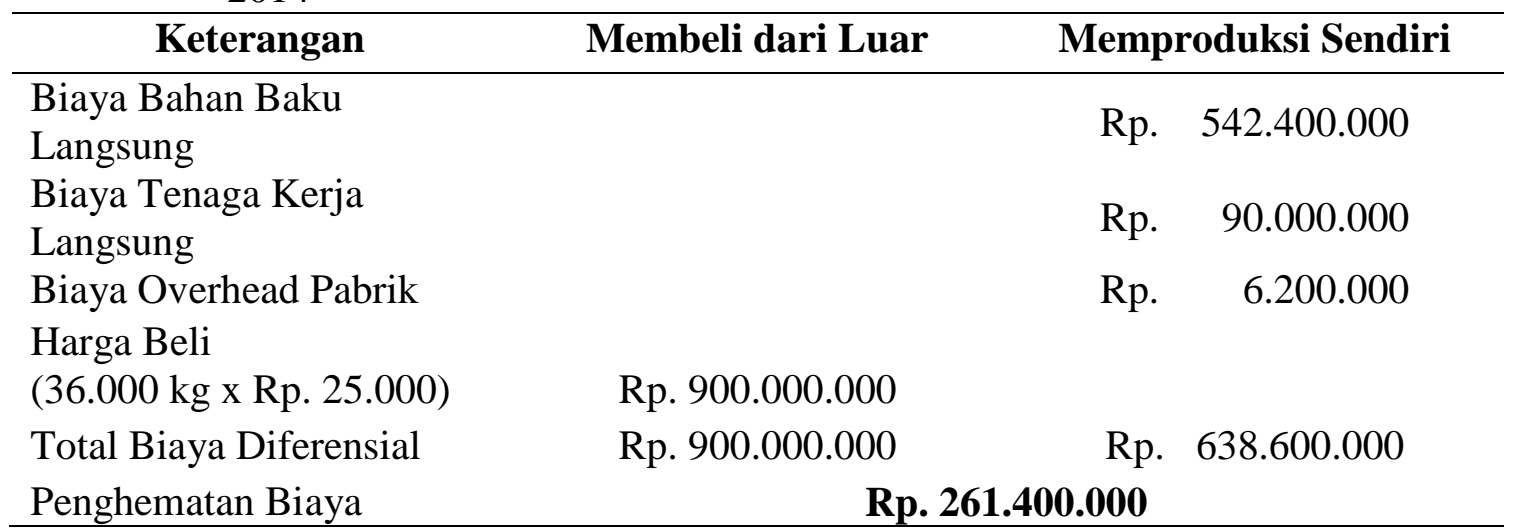

Sumber :Hasil data olahan, 2015

\section{Tinjauan Berdasarkan Laba Diferensial}

Dalam pengambilan keputusan membeli atau memproduksi sendiri tersebut informasi akuntansi yang relevan adalah dengan menggunakan laba diferensialnya, yaitu seperti pada tabel4.5 berikut ini : 
Tabel 4.5. Laporan laba/rugi Membeli atau memproduksi sendiri Periode 2014

\begin{tabular}{lcc}
\multicolumn{1}{c}{ Keterangan } & Membeli dari Luar & Memproduksi Sendiri \\
\hline Penjualan & Rp. 3.240.000.000 & Rp. 3.240.000.000 \\
$\begin{array}{l}\text { Biaya Bahan Baku Langsung } \\
\text { Biaya Tenaga Kerja }\end{array}$ & Rp. 542.400 .000 \\
$\begin{array}{l}\text { Langsung } \\
\text { Biaya Overhead Pabrik }\end{array}$ & Rp. 90.000 .000 \\
Harga Beli & & Rp. 6.200 .000 \\
(36.000 kg x Rp. 25.000) & Rp. 900.000 .000 & \\
Total Biaya Diferensial & Rp. 900.000.000 & Rp.638.600.000 \\
$\begin{array}{l}\text { Penjualan Biaya Diferensial } \\
\text { Penghematan Biaya }\end{array}$ & Rp.2.340.000.000 & Rp. 2.601.400.000 \\
\hline Rp. 261.400.000
\end{tabular}

Sumber :Hasil Data Olahan, 2015

\section{Analisis Biaya Peluang}

Jika RM.Pondok Hijau membeli Ikan dari luar , maka sebagian fasilitas menganggur seperti telaga, selama menganggur terdapat peluang untuk disewakan kepada pihak lain sebesar Rp. 250.000 .000 selama 1 tahun dengan lebar 20 meter $^{2}$ dan panjang 40 meter $^{2}$.

Dengan asumsi ini berarti akan terjadi biaya peluang sebesar Rp. 250.000.000, dan perhitungan yang dilakukan adalah sebagai berikut :

\begin{tabular}{ccc} 
Total Biaya Membeli Dari Luar & Rp. & 900.000 .000 \\
Biaya Peluang & Rp. & $(250.000 .000)$ \\
\cline { 2 - 3 } Total Biaya diperhitungkan & Rp. & 650.000 .000
\end{tabular}

Berdasarkan hasil perhitungan biaya peluang dengan biaya membeli dari luar yang merupakan biaya yang diperhitungkan yaitu sebesar Rp. 650.000.000 maka membeli dari luar menduduki posisi lebih mahal dibandingkan dengan memproduksi sendiri yaitu sebesar Rp. 638.600.000 (Lihat Tabel 4.5) sehingga pada posisi ini keputusan memproduksi sendiri masih lebih menguntungkan.

\section{KESIMPULAN}

Berdasarkan hasil penelitian dan pembahasan yang telah dikemukakan sebelumnya, maka dapat diambil kesimpulan sebagai berikut :

1. Berdasarkan hasil analisis mengenai biaya diferensial, khususnya pengambilan keputusan membeli atau memproduksi sendiri, menunjukkan bahwa sebaiknya RM. Pondok Hijau memilih alternatif memproduksi sendiri dari pada membeli dari luar karena dengan memproduksi ikan sendiri terjadi penghematan biaya yang cukup besar sehingga bisa lebih menguntungkan usaha RM. Pondok Hijau. Dan hasil penelitian yang ditinjau dari laba diferensial adalah sebaiknya RM.Pondok Hijau memproduksi sendiri ikan karena mendapatkan selisih laba yang tinggi dibandingkan membeli dari luar ikan agar supaya menguntungkan perusahaan

2. Berdasarkan hasil analisis dari biaya peluang yang muncul jika RM.Pondok Hijau menyewakan lahan telaga mereka, memproduksi sendiri menduduki posisi lebih murah sehingga pada posisi ini keputusan memproduksi sendiri tetap lebih menguntungkan.

3. Berdasarkan hasil penelitian Rumah makan yang di teliti memilih alternatif membeli dari luar Ikan. Karena dalam memproduksi ikan membutuhkan jangka waktu 3 bulan sehingga tidak memungkinkan rumah makan memproduksi ikan untuk kebutuhan sehari. Dan jumlah pesanan ikan yang banyak tiap harinya jadi perusahaan memilih alternatif yang paling cepat dan gampang yaitu membeli dari luar ikan. 
Berdasarkan hasil penelitian ini adapun saran yang diajukan penulis sebagai bahan pertimbangan perusahaan yaitu RM. Pondok Hijau sebaiknya mengambil keputusan untuk memproduksi sendiri bahan baku ikan karena biaya yang akan dikeluarkan lebih rendah dari pada membeli dari luar bahan baku sehingga dapat melakukan penghematan biaya dan juga akan lebih menguntungkan untuk perusahaan. Saran penulis sebaiknya perusahaan menggunakan telaga yang tidak terpakai untuk memproduksi sendiri ikan karena dengan memproduksi sendiri ikan, perusahaan akan melakukan penghematan biaya dan juga kualitas ikan yang dipelihara sendiri akan lebih baik dan terjaga dari pada membeli dari luar.

\section{DAFTAR PUSTAKA}

Arfan, Ikhsan. (2009). Pengantar Praktis Akuntansi. Edisi pertama, graha ilmu, Yogyakarta.Garrison,

Darsono Prawironegoro, Purwanti, Ari. (2009). Akuntansi Manajemen. Jilid 1.Edisi keempat.Erlangga. Jakarta

Halim, Abdul. Bambang, Supomo. Kusufi, Syam Muhammad,. (2013). Akuntansi Manajemen.Edisi ke Dua.BPFE. Yogyakarta

Hansen, Don R., Mowen, Maryanne M. (2004). Akuntansi Manajemen. Jilid 1.Edisi ke empat.Erlangga.

Hongren, Datar, Foster, George,. (2009). Akuntansi Manajemen.Jilid 1.Edisi ke empat.Erlangga. Jakarta

Iqbal, Mohamad,. (2013). Pengaruh Biaya Diferensial Terhadap Proses Pengambilan Keputusan Manajemen Memproduksi Sendiri Atau Membeli Produk (Studi pada PT. Fintex) Jbtunpaspp-gdl-mohammadiq-2650-1-skripsi

Kamaruddin Ahmad,. (2013). Akuntansi Manajemen: Dasar-dasar konsep biaya dan pengambilan keputusan, Edisi Revisi 8, Rajawali Pers Bisnis, Jakarta

Krismiaji, Aryani,. (2011). Akuntansi Manajemen. Edisi Kedua. UPP STIM YKPN. Yogyakarta pengambilan Keputusan. Edisi Kelima, Penerbit Raja Grafindo Persada,Jakarata.

Mulyadi, (2001).Akuntansi Manajemen : Konsep, Manfaat dan Rekayasa, Edisi Ketiga. Salemba Empat. Jakarta

Mursyidi, (2008).Akuntansi Manajemen, Konsep, Manfaat dan Rekayasa. Edisi ketiga. Salemba Empat. Jakarta.Munawir, S, 2002.

Rantung, Dewinta., (2014). Penerapan Biaya Diferensial Dalam Pengambilan Keputusan Membeli Atau Memproduksi Sendiri Pada Rm. Pangsit Tompaso. JurnalEMBA ISSN 2303-1174

Vol.2

http;//ejournal.unsrat.ac.id/index.php/emba/article/viewFile/5067/4585. Diakses 3 September 2014. Hal 030-037.

Salman, Kautsar. (2013). Akuntansi Biaya, Cetakan Pertama. Akademia Permata Jakarta

Simamora, Henry,. (2012). Akuntansi Manajemen. Edisi III. Penerbit Star Gate Publisher Duri. Riau.

Sujarweni, Wiratna,. (2014). Metodologi Penelitian. Pustaka baru, Yogyakarta

Supomo, Bambang. (2012). Akuntansi Manajemen Suatu Sudut Pandang. Penerbit; BPFE, Yogyakarta

Tumbol, Wanda,. (2014). Analisis Dengan Menggunakan Informasi Akuntansi Diferensial Dalam Pengambilan Keputusan Membeli Atau Membuat Sendiri Bakso Pada Bakso Pasuruan. Jurnal EMBA ISSN 2303-1174 Vol.2, http;//ejournal.unsrat.ac.id/index.php/emba/article/viewFile/.../43333. Diakses 7 Juli 2014. Hal 1440-1447.

Wildilestariningtyas, Ony, Anggraini, Sri, Firdaus, Dony. (2012). Akuntansi Biaya Graha Ilmu. Yogyakarta. 
Witjaksono, Armanto. (2006). Akuntansi Biaya, Jilid 1, Edisi Pertama, Penerbit : Graha Ilmu, Yogyakarta. 